ISSN 1991-8631

Original Paper

http://indexmedicus.afro.who.int

\title{
Degradation of aviation fuel by microorganisms isolated from tropical polluted soils
}

\author{
Ayodele Elizabeth OMOTAYO*, Okiemute Ajirie EFETIE, Ganiyu OYETIBO, \\ Matthew Olusoji IlORI and Olukayode Oladipo AMUND \\ Department of Microbiology, University of Lagos, Lagos, Nigeria. \\ *Corresponding author, E-mail: elizabethomotayo@yahoo.com; Tel: (234) 80-33723181
}

\begin{abstract}
The degradation of aviation fuel was observed in soil samples from a polluted site at the aviation fuel depot, Lagos Airport, Nigeria. The percentage of occurrence of bacterial aviation fuel-utilizers were less than $1.0 \%$ of the heterotrophic populations, while the fungal-degraders were between $2.547-16.053 \%$. There were no significant statistical differences for both the bacteria and fungi estimations among the soil samples. Enrichment of soil samples with aviation fuel resulted in the isolation of five bacteria (Pseudomonas aeruginosa, Micrococcus luteus, Corynebacterium sp., Flavobacterium rigense, Bacillus subtilis), three yeasts (Rhodotorula sp., Candida tropicalis, Saccharomyces sp.) and two molds (Aspergillus niger, Penicillium sp.). Utilization of the substrate by bacteria and yeast isolates resulted in an increase in population density and subsequent decrease in $\mathrm{pH}$ value and residual aviation fuel concentration. Over $90 \%$ of the $n$-alkane fraction of the aviation fuel supplied at $0.5 \% \mathrm{v} \mathrm{v}^{-1}$ concentration was degraded in 14 days by Pseudomonas aeruginosa, Micrococcus luteus and Corynebacterium sp. There were differential growth responses by the strains to dodecane, benzene, toluene and naphthalene, while growth was not supported by hexane and cyclohexane. Thus, enrichment with of soil contaminated with aviation fuel led to the isolation of competent hydrocarbon degraders.
\end{abstract}

(c) 2011 International Formulae Group. All rights reserved.

Keywords: Aviation fuel, hydrocarbon, biodegradation, bacteria, yeast, soil.

\section{INTRODUCTION}

The growth of petroleum industry in Nigeria and the demand of petroleum products have made oil pollution a serious environmental problem. Contamination of the environment may result from seepage from natural deposits, human activities in the production, transportation and storage of petroleum products or from accidental events (Balba et al., 1998). Whatever the origin of the contamination, there is the possibility that some may enter the soil environment and this may present a direct risk of ground water contamination, lakes or water-course providing water for domestic and industrial use. Although a significant proportion of the compounds in crude oil are relatively harmless, a number, especially the lower molecular weight compounds are toxic or mutagenic and require remedial action to ameliorate environmental damage following a spill. Fortunately, when natural ecosystems 
are contaminated with petroleum hydrocarbons, the indigenous microbial populations of different taxonomic relationships which are capable of degrading the contaminating hydrocarbons proliferate and degrade them (Amund et al., 1987; Widdel and Rabus, 2001). Unfortunately the biodegradation of hydrocarbons in soil is often relatively slow and it is therefore desirable to decontaminate locations that have had high cumulative or shock loadings of petroleum. One of the best approaches to restoring contaminated soils is to make use of microorganisms able to degrade those toxic compounds in a bioremediation process (Fatima et al., 2005).

In this study, we have attempted to identify the microorganisms which can utilize aviation fuel as carbon and energy source from an aviation-polluted soil and examined their abilities to grow on a range of pure hydrocarbon substrates.

\section{MATERIALS AND METHODS Sample collection}

Soil samples were collected from an aviation fuel depot at the Murtala Muhammed International Airport, Lagos, Nigeria. The samples were from a region of highly polluted ( $\mathrm{pH}$ 6.5), lightly polluted ( $\mathrm{pH}$ 6.6) and nonaviation polluted soil ( $\mathrm{pH}$ 6.7) within the same location designated $\mathrm{A}, \mathrm{B}$ and $\mathrm{C}$ respectively. The samples were collected from five different spots at each location and 20 meters apart from each location to a depth of $10-20$ $\mathrm{cm}$ in sterile bottles; these were homogenized and taken to the laboratory immediately for analysis or refrigerated at $4{ }^{\circ} \mathrm{C}$ before use.

\section{Chemicals}

Aviation kerosene was obtained from Total petroleum depot, Apapa, Lagos. All other chemicals used were of reagent grade standard. For the isolation and enumeration of microbial population of the soil samples, the total heterotrophic populations of bacteria and fungi were determined by spread plate method on nutrient agar (NA) and yeast extract agar
(YEA) respectively. The total aviation fuelutilizing populations of bacteria and fungi were determined as described by Amund et al. (1987). The aviation fuel-degrading bacteria and fungi were isolated by standard plate culture technique on Mineral Salts (MS) medium described by Kastner et al. (1994) and solidified with purified agar $(1.5 \%)$. The medium contains per litre $\mathrm{Na}_{2} \mathrm{HPO}_{4}, 2.13 \mathrm{~g}$; $\mathrm{KH}_{2} \mathrm{PO}_{4}, \quad 1.30 \mathrm{~g} ; \quad \mathrm{NH}_{4} \mathrm{Cl}, \quad 0.50 \mathrm{~g}$ and $\mathrm{MgSO}_{4} \cdot 7 \mathrm{H}_{2} \mathrm{O}, 0.20 \mathrm{~g}$. Trace elements solution $\left(1 \mathrm{ml} \mathrm{l}^{-1}\right)$ of Bauchop and Elsden (1969) was added to the medium and ampicillin $(0.125 \mathrm{~g}$ $\mathrm{l}^{-1}$ ) was added to YEA to prevent bacterial contamination in the fungal cultures. The $\mathrm{pH}$ was adjusted to 7.2 and 5.8 for bacterial and fungal growth respectively. Aviation fuel served as sole source of carbon and energy, which was supplied through vapour phase transfer as described by Amund et al. (1987). Plates were incubated at room temperature (25-28 $\left.{ }^{\circ} \mathrm{C}\right)$ for $5-7$ days.

\section{Enrichment and isolation of aviation fuel- degrading bacteria and fungi}

Bacteria and fungi able to degrade aviation fuel were isolated on mineral salts (MS) medium by continual enrichment method (Churchill et al., 1999). The mineral medium described by Kastner et al. (1994) was used. The $\mathrm{pH}$ of the medium for bacteria was adjusted to 7.2 and fortified with nystatin at $50 \mu \mathrm{g} \mathrm{ml}^{-1}$ to suppress fungal growth, while $\mathrm{pH}$ for fungal medium was adjusted to 5.8 and $0.125 \mathrm{~g} \mathrm{l}^{-1}$ ampicillin was added to suppress bacteria. Trace elements solution (1 $\mathrm{ml}$ per litre) described by Bauchop and Elsden (1969) was sterilized separately and added aseptically to the medium. Contaminated aviation-soil sample $\left(10 \% \mathrm{wV}^{-1}\right)$ was added to the MS medium containing $0.5 \%\left(\mathrm{v} \mathrm{v}^{-1}\right)$ aviation fuel. Enrichment was carried out with shaking at $150 \mathrm{rev} \min ^{-1}$ for two weeks. After three consecutive transfers, aviation-fuel degraders were isolated and purified by plating out dilutions from the final flasks on MS medium agar. The ability of the isolates to degrade aviation fuel was confirmed by inoculating 
washed broth cultures of each isolate $(24 \mathrm{~h})$ into $250 \mathrm{ml}$ erlenmeyer flasks containing 50 ml MS medium supplemented with $0.5 \%$ $\left(\mathrm{v} \mathrm{v}^{-1}\right)$ aviation fuel as sole carbon and energy source. This was cultivated at room temperature for 7 days. Isolates with good aviation fuel-degradative competency evidenced by intense turbidity of the culture fluid and total disappearance of aviation fuel were selected for further studies. The isolates were maintained on NA and YEA slants at 4 ${ }^{0} \mathrm{C}$ and subcultured every 2 weeks to maintain purity and viability.

\section{Identification of isolates}

The isolates were identified on the basis of their cultural, cellular and biochemical characteristics. They were subsequently classified based on the taxonomic schemes and description by Collins and Lyne (1984), Smith (1969) and Cowan and Steel (1990).

\section{Substrate specificity}

This was carried out using the method of Amund et al. (1987). Various hydrocarbons were introduced into conical flask containing MS medium inoculated with test organisms. The controls consisted of killed isolates in MS medium plus each of the substrates. Degradation was monitored by measuring increase in cell density. The hydrocarbons tested include hexane, dodecane, cyclohexane, benzene, toluene, naphthalene and aviation fuel. Liquid hydrocarbons were autoclaved and separately added to sterile MS medium at $0.5 \%\left(\mathrm{vv}^{-1}\right)$. The flasks were agitated on a shaker at $120 \mathrm{rev} \mathrm{min}^{-1}$ at room temperature $\left(30{ }^{\circ} \mathrm{C}\right)$ for 7 days.

\section{Growth kinetics experiments}

The bacterial and fungal strains were grown aerobically in $100 \mathrm{ml}$ of MS medium contained in erlenmeyer flasks $(250 \mathrm{ml})$ supplemented with $0.5 \%\left(\mathrm{vv}^{-1}\right)$ aviation fuel as the sole carbon and energy source. Incubation was carried out at $150 \mathrm{rev} \mathrm{min}^{-1}$ at room temperature. The experiment was monitored for 14 days at 2-day interval. Population densities were determined by plate counts by measuring the Total Viable Counts (TVC) on NA and YEA. Changes in $\mathrm{pH}$ values were also recorded.

\section{Extraction of residual oil}

Methylene chloride was used in extracting residual aviation-fuel from the culture samples. Extraction was carried out by adding $10 \mathrm{ml}$ of vigorously shaken culture to $10 \mathrm{ml}$ of methylene chloride. The mixtures were vigorously shaken and allowed to settle for 10-15 $\mathrm{min}$ to separate aqueous and organic phases. The organic layer was drawn off and quantified chromatographically. The control flasks were extracted similarly.

\section{Gas chromatographic analysis of oil}

The extracted oil $(0.5 \mu \mathrm{g})$ were analyzed by GC (Hewlett Packard 5890 series 11) fitted with flame ionization detector and AJ \& W Scientific DB-1 fused silica capillary, $15 \mathrm{~m}$ long column (internal diameter, 0.32 $\mathrm{mm}$; film thickness $1.0 \mu \mathrm{m})$. The injector and detector temperatures were maintained at 300 and $325{ }^{\circ} \mathrm{C}$ respectively. The column temperature was programmed to rise from 50 to $305{ }^{\circ} \mathrm{C}$ for $27 \mathrm{~min}$. The carrier gas was helium. The data were digitalized using a model 760 A/D converter from Nelson Analytical software for processing.

\section{Statistical analysis}

The mean, analysis of variance and growth kinetics were performed using the GraphPad Prism version 5.00 computer software programme (GraphPad Software, San Diego, CA). Significance limits were set at the $95 \%$ confidence interval level.

\section{RESULTS}

\section{Enumeration of microbial populations}

The percentage of occurrence of bacterial aviation fuel-utilizers presented in Table 1 was observed to be generally less than $1.0 \%$ of the heterotrophic populations, while the fungal-degraders were between 2.547- 
$16.053 \%$. The heavily contaminated soil had the least population density of bacteria and fungi (heterotrophs) and total aviation fuel utilizing bacteria. Interestingly, it also gave the highest percentage of fungi-degraders. The total heterotrophic bacteria and fungi populations for the soil samples were higher than the aviation fuel-utilizing bacteria and fungi populations. One-way analysis of variance showed no statistical difference among the three soil samples, for both the bacterial and fungal load estimations.

\section{Identification of microbial strains}

Many isolates were obtained from the enrichment cultures but only those that could grow on aviation-fuel alone as carbon and energy source were identified on the basis of their cultural, morphological and biochemical properties. The bacterial species were Pseudomonas aeruginosa, Micrococcus luteus, Corynebacterium sp., Flavobacterium rigense and Bacillus subtilis. The yeast isolates were Rhodotorula sp., Candida tropicalis and Saccharomyces sp., while the molds include Aspergillus niger and Penicillium sp. The bacteria and yeasts isolates were selected for further studies.

\section{Substrate specificity test}

The result of hydrocarbon substrate specificity (Table 2) revealed that all the isolates utilized aviation fuel but not hexane and cyclo-hexane. Dodecane supported the growth of all the isolates weakly, while Bacillus subtilis could not thrive on it. None of the yeast isolates could grow on benzene, however Pseudomonas aeruginosa and Flavobacterium rigense utilized it weakly. Furthermore, toluene and naphthalene sparingly supported the growth of Micrococcus luteus, Bacillus subtilis and Candida tropicalis while the other isolates could not metabolize the substrates. The controls were all negative utilizers.

\section{Growth kinetics of isolates on aviation fuel}

Biodegradation experiment with the isolated degraders of aviation fuel from the soil, revealed a steady increase in turbidity and decrease in $\mathrm{pH}$ of the culture media (7.16 to 6.01) during the 14-day incubation period (Figure 1A -E). The mean generation time ranged between 1.12 and 3.34 days (Table 3). Pseudomonas aeruginosa had a growth yield of 0.025 day $^{-1}$ with over $90 \%$ of the $n$-alkane fraction of the aviation fuel utilized (Table 3). The growth dynamics showed a consistent increase in population density ( $\log 5.57$ 7.69) from day 0 until day 10 after which it declined. Growth kinetics of Corynebacterium sp. showed a similar trend with that of $P$. aeruginosa (Figure 1C). Aviation-fuel utilization by Micrococcus luteus and Bacillus subtilis resulted in growth rate of two orders of magnitude in the culture media (Figure 1B and E). The growth kinetics of Flavobacterium rigense exhibited a lag phase from day 0 to 2 before a steady increase up to day 12 and a decline subsequently (Figure 1D). The growth kinetics of Rhodotorula sp., Candida tropicalis and Saccharomyces sp. showed that the $\mathrm{pH}$ declined and growth increased by 2 orders of magnitude in their culture media (Figure 2A-C). In the control flask there was no apparent decrease in the substrate and the $\mathrm{pH}$ of the medium remained constant. The GC profile of culture extracts of some of the bacterial strains revealed that there was a marked disappearance of the $n$ alkane peaks in the chromatograms of the bacterial cultures and the hydrocarbons were not fully degraded at the $14^{\text {th }}$ day termination of the experiment as evident by the peak pattern of the chromatograms (chromatogram not shown). However, over $90 \%$ of the $n$ alkane fraction of the aviation fuel substrate was degraded by the organisms within the 14 day incubation period (Table 3 ). 
Table 1: Population of heterotrophic and hydrocarbon-utilizers in soil.

\begin{tabular}{|c|c|c|c|c|c|c|c|}
\hline \multicolumn{4}{|l|}{ Bacteria } & \multicolumn{4}{|l|}{ Fungi } \\
\hline Sample & $\begin{array}{l}\text { Total heterotrophs } \\
*\left(\text { cfu } \times 10^{7}\right)\end{array}$ & $\begin{array}{l}\text { Total aviation fuel- } \\
\text { utilizers } *\left(\mathbf{c f u} \times \mathbf{1 0}^{4}\right)\end{array}$ & \%aviation fuel-utilizers & Sample & $\begin{array}{l}\text { Total heterotrophs } \\
*\left(\text { cfu } \times 10^{5}\right)\end{array}$ & $\begin{array}{l}\text { Total aviation fuel- } \\
\text { Utilizers } *\left(\mathbf{c f u} \times \mathbf{1 0}^{4}\right)\end{array}$ & $\begin{array}{l}\text { \%aviation fuel- } \\
\text { utilizers }\end{array}$ \\
\hline A & 2.70 & 3.45 & 0.128 & A & 1.90 & 3.05 & 16.052 \\
\hline B & 7.45 & 6.30 & 0.085 & B & 3.30 & 2.30 & 6.969 \\
\hline $\mathrm{C}$ & 4.35 & 8.10 & 0.190 & $\mathrm{C}$ & 8.05 & 2.05 & 2.547 \\
\hline
\end{tabular}

A, heavily contaminated soil; B; lightly contaminated soil; C, non-contaminated soil (control); cfu, colony forming units per ml; *, average of three replicate determinations.

Table 2: Hydrocarbon substrate specificity of isolates.

\begin{tabular}{|c|c|c|c|c|c|c|c|c|c|}
\hline \multirow[t]{2}{*}{ Substrate } & \multicolumn{8}{|c|}{ Isolate } & \multirow[b]{2}{*}{ Control } \\
\hline & S1 & S2 & S3 & S4 & S5 & Y1 & Y2 & Y3 & \\
\hline Hexane & - & - & - & - & - & - & - & - & - \\
\hline Dodecane & + & ++ & ++ & + & - & ++ & + & + & - \\
\hline Cyclo-hexane & - & - & - & - & - & - & - & - & - \\
\hline Benzene & + & - & - & + & - & - & - & - & - \\
\hline Toluene & - & + & - & - & + & - & + & - & - \\
\hline Naphthalene & - & + & - & - & - & - & + & - & - \\
\hline Aviation fuel & ++ & ++ & ++ & ++ & ++ & +++ & +++ & +++ & - \\
\hline
\end{tabular}

Y2, Candida tropicalis; Y3, Saccharomyces sp.; control, killed isolates in substrates; +, poor growth; ++, moderate growth; +++, heavy growth. 
Table 3: Growth rates of aviation-fuel utilizing microbial strains.

\begin{tabular}{lllll}
\hline Isolate & $\begin{array}{l}\text { Doubling time } \\
(\mathbf{d a y})\end{array}$ & $\begin{array}{l}\text { Mean generation time } \\
(\mathbf{d a y})\end{array}$ & $\begin{array}{l}\text { Specific growth rate } \\
\left(\mathbf{d a y}^{\mathbf{1}}\right)\end{array}$ & $\begin{array}{l}\text { Aviation fuel degraded } \\
(\boldsymbol{\%}))^{*}\end{array}$ \\
\hline Pseudomonas aeruginosa & 0.77 & 1.12 & $0.90 \pm 0.52$ & 96.57 \\
Micrococcus luteus & 2.31 & 3.34 & $0.30 \pm 0.07$ & 95.80 \\
Corynebacterium sp. & 1.91 & 2.76 & $0.36 \pm 0.09$ & 96.46 \\
Flavobacterium rigense & 1.45 & 2.09 & $0.48 \pm 0.02$ & - \\
Bacillus subtilis & 1.72 & 2.48 & $0.40 \pm 0.05$ & - \\
Rhodotorula sp. & 1.76 & 2.54 & $0.39 \pm 0.04$ & 96.51 \\
Candida tropicalis & 0.84 & 1.22 & $0.82 \pm 0.02$ & - \\
Saccharomyces sp. & 1.42 & 2.05 & $0.49 \pm 0.01$ & \\
& & &
\end{tabular}

Data presented are means of three replicate determinations. Aviation-fuel was supplied at $0.5 \%(\mathrm{v} \mathrm{v}-1) ;{ }^{*}, \mathrm{n}$-alkane fraction 

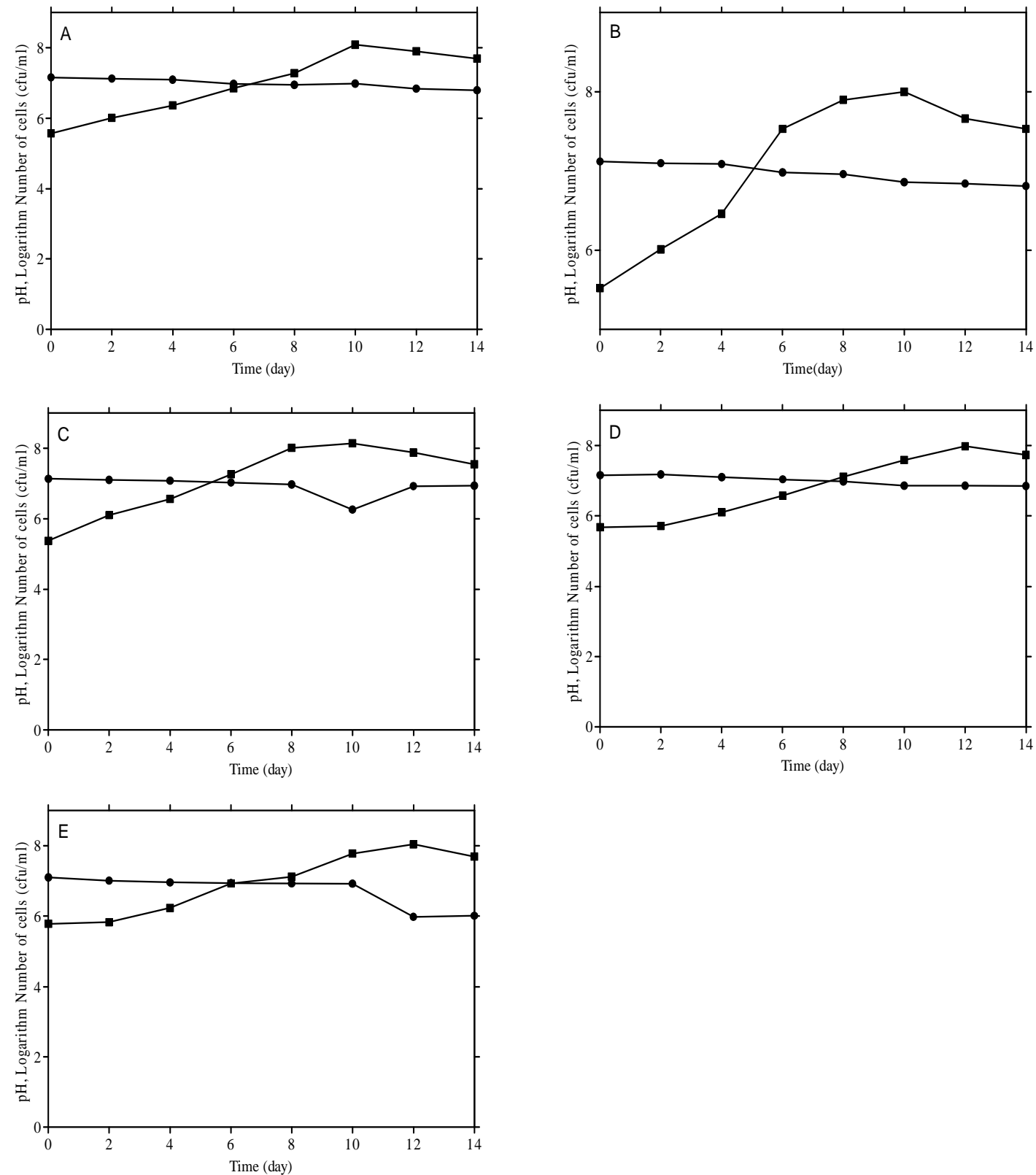

Figure 1: Growth of Pseudomonas aeruginosa (A), Micrococcus luteus (B), Corynebacterium sp. (C), Flavobacterium rigense (D) and Bacillus subtilis (E) on aviation fuel. $\bullet$, pH; $\mathbf{\square}$, logarithm number of cells $(\mathrm{cfu} / \mathrm{ml})$. Values are means of three replicate determinations. 

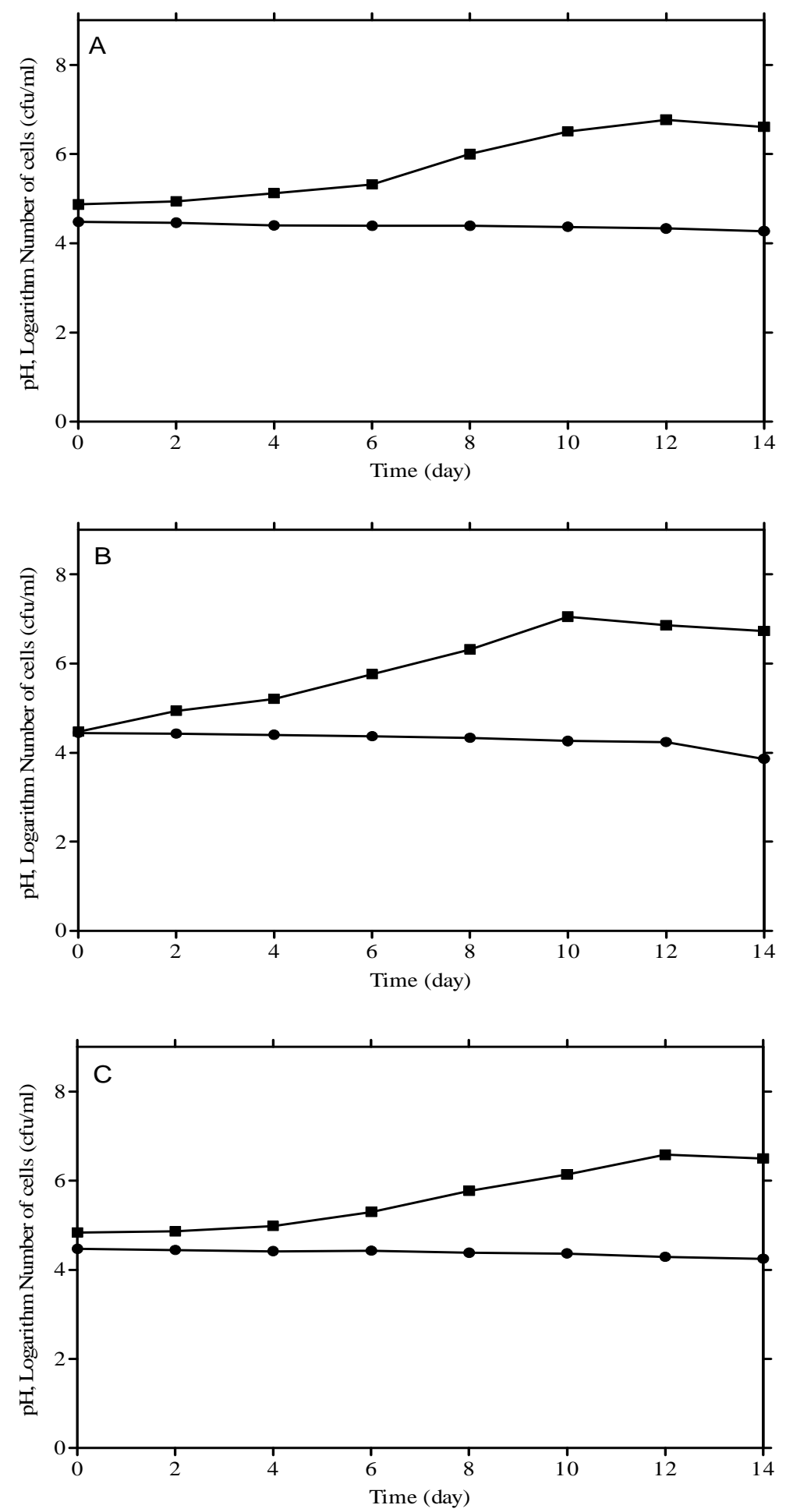

Figure 2: Growth of Rhodotorula sp. (A), Candida tropicalis (B) and Saccharomyces sp. (C) on aviation fuel. •, $\mathrm{pH}$; $\mathbf{\square}$, logarithm number of cells ( $\mathrm{cfu} / \mathrm{ml})$. Values are means of three replicate determinations. 


\section{DISCUSSION}

One of the strategies for environmental restoration of oil polluted sites involves understanding the impact of oil pollution and its elimination from the environment. Hydrocarbons are naturally occurring organic compounds and the ability to utilize hydrocarbon is widely distributed among diverse microbial populations.

In this study, we have attempted to demonstrate the potential degradability of aviation fuel and a range of hydrocarbon substrates by microorganisms isolated from an aviation fuel depot soil. The difference in population densities between the total heterotrophic population and the total aviation fuel-utilizers corroborates the findings of Fagade and Oso (2000). The population density of total heterotrophs was greater compared to the oil degrading population. Hydrocarbon degrading bacteria and fungi are heterotrophs, so naturally, there should be more heterotrophs than degraders (a subpopulation). The microbial population of the contaminated site revealed that the heavily contaminated soil had the least population densities for both bacteria and fungi. Usually, toxic components of petroleum may selectively inhibit microorganisms producing a shift in population size and species diversity within the soil (Bossert and Bartha, 1984; Labud et al., 2007). Also, the addition of petroleum hydrocarbons to the soil environment affects soil properties which ultimately affect the microbial community (Franco et al., 2004; Labud et al., 2007; Erdogan and Karaca, 2011).

The enrichment of the soils resulted in the isolation of more bacteria compared to yeasts and molds. Hydrocarbons are degraded primarily by bacteria and fungi. Bacteria are considered to represent the predominant agents of hydrocarbon degradation in the environment (Leahy and Colwell, 1990) and hydrocarbon-degrading bacteria are ubiquitous (Röling et al., 2002). The bacterial genera isolated have also been identified by other researchers to contain species that together can degrade most constituents of crude oil, including the aliphatic, alicyclic, aromatic and polycyclic hydrocarbons (Ko and Lebault, 1999; Fagade and Oso, 2000). Species of yeast such as Candida sp. and Saccharomyces have also been reported to utilize oil (Amund and Nwokoye, 1993).

Aviation fuel was utilized as growth substrate by all the microbial strain. This may be because the strains were isolated from an aviation fuel contaminated site and selected for their ability to grow on it as carbon and energy source. Hexane and cyclohexane (alkanes of lower molecular weight) were not employed by the strains as a medium for growth. Dodecane, a liquid alkane, and the aromatic hydrocarbon substrates (benzene, toluene and naphthalene) were selectively utilized by the strains poorly or not at all. Microbial degradation of crude oil is often shown to occur by attack on alkanes or light aromatic fractions, while the higher molecular weight aromatics, resins and asphaltenes are considered recalcitrant (Lal and Khanna, 1996). It is generally accepted that the susceptibility of hydrocarbons to microbial attack decreases in the following order: $n$ alkanes > branched alkanes > low-molecular weight aromatics > cyclic alkanes (Obbard et al., 2004; Labud et al., 2007). Crude oil, particularly the aromatic fractions, is acutely lethal to agricultural soils, even in concentrations of few parts per million and chronically lethal in sub-lethal concentrations in parts per billion (Odiete, 1999). Affected soils lose their fertility and become unproductive (Nwachukwu and Ugoji, 1995), but within a few years crude oil contaminated soils generally return to full productivity (Kisic et al., 2009).

The increase in growth dynamics is similar to that obtained by Adebusoye et al. (2007) in their study of a polluted stream. Growth dynamics is attributed to either the constitutive nature of hydrocarbonassimilating capabilities in the organisms or reflects the adaptation of the strains as a result of previous exposure to exogenous 
hydrocarbons, which may be followed by concomitant development of the ability to use the oil and/or its catabolic products as carbon and energy source (Adebusoye et al., 2007). The reduction in the $\mathrm{pH}$ levels may have resulted from organic acids produced in the cultures. This corroborates the works of Amund and Adebiyi (1991) and Okpokwasili and James (1995) that microbial utilization of hydrocarbons lead to production of organic acids. The incomplete degradation of aviation fuel shows that the fuel contains components which may be recalcitrant.

This work has shown the occurrence of pure strains of various bacteria, yeasts and molds with the capacity to utilize aviation fuel and only limited range of hydrocarbon substrate in their pure state. The data obtained support the general idea now accepted by the scientific community that no species of microorganisms will completely degrade any particular oil (Erdogan and Karaca, 2011). The degradation of both crude and refined oils usually involves a consortium of microorganisms, including both eukaryotic and prokaryotic forms (Ko and Lebeault, 1999; Röling et al., 2002). In reality, all the strains obtained would be working together to bring about the remedial action of the contaminated site. Thus the focus of our next work would be to combine the strains obtained as consortia and enhance their performance in order to bring about the total recovery of the contaminated soil.

\section{REFERENCES}

Adebusoye SA, Ilori MO, Amund OO, Teniola OD, Olatope SO. 2007. Microbial degradation of petroleum hydrocarbons in a polluted tropical stream. World $J$. Microbiol. Biotechnol., 23: 1149-1159.

Amund OO, Adebiyi AG. 1991. Effect of viscosity on the biodegradability of automotive lubricating oils. Tribol. Intern., 24: 235-237.

Amund OO, Adebowale AA, Ugoji EO. 1987. Occurrence and characterization of hydrocarbon utilizing bacteria in Nigerian soils contaminated with spent motor oil. Ind. J. Microbiol., 27: 63-87.

Amund OO, Nwokoye N. 1993. Hydrocarbon degradation potentials of yeast isolates from a polluted lagoon. J. Sci. Res. Dev., 1: $65-68$.

Balba MT, Al-Awadhi N, Al-Daher R. 1998. Bioremediation of oil-contaminated soil: microbiological methods for feasibility assessment and field evaluation. $J$. Microbiol. Methods, 32: 155-164.

Bauchop T, Elsden SR. 1969. The growth of microorganisms in relation to their energy. J. Gen. Microbiol., 23: 457-459.

Bossert I, Bartha R. 1984. The fate of petroleum in soil ecosystems. In Petroleum Microbiology, Atlas RM (ed). Macmillan Inc.: New York; 435-473.

Churchill SA, Harper JP, Churchill PF. 1999. Isolation and characterisation of a Mycobacterium species capable of degrading three-and four-ring aromatic and aliphatic hydrocarbons. Appl. Environ. Microbiol., 65: 549-552.

Collins CM, Lyne PM. 1984. Microbiological Methods $\left(6^{\text {th }}\right.$ edn). Butterwort and Co. Ltd: London, UK; 56-113.

Cowan ST, Steel KJ. 1990. Manual for the Identification of Medical Bacteria. Cambridge University Press: Cambridge; 355.

Erdogan EE, Karaca A. 2011. Bioremediation of crude oil polluted soils. Asian $J$. Biotechnol., 3: 206-213.

Fagade OE, Oso BA. 2000. Bacteria species diversity in three crude-oil-impacted water-bodies in the Niger Delta of Nigeria. J. Sci. Res., 6: 20-24.

Fatima M, Flavio A, Benedict C, William T. 2005. Comparative bioremediation of soils contaminated with diesel oil by natural attenuation, biostimulation and bioaugmentation. Bioresource Tech., 96: 1049-1055.

Franco I, Contin M, Bragato G, De Nobili M. 2004. Microbiological resilience of soils contaminated with crude oil. Geoderma, 121: 17-30. 
Kastner M, Breuer-Jammali M, Mahro B. 1994. Enumeration and characterisation of the soil microflora from hydrocarboncontaminated soil sites able to mineralise polycyclic aromatic hydrocarbons. Appl. Microbiol. Biotechnol., 41: 267-273.

Kisic I, Mesic S, Basic F, Brkic V, Mesic M, Durn G, Zgorelec Z, Bertovic L. 2009. The effect of drilling fluid and crude oil on some chemical characteristics of soil and crops. Geoderma, 149(3-4): 209-216.

Ko SH, Lebeault JM. 1999. Effect of a mixed culture on co-oxidation during the degradation of saturated hydrocarbon mixture. J. Appl. Microbiol., 87: 72-79.

Labud V, Garcia C, Hernandez T. 2007. Effect of hydrocarbon pollution on the microbial properties of a sandy and a clay soil. Chemosphere, 66: 1863-1871.

Lal B, Khanna S. 1996. Degradation of crude oil by Acinetobacter calcoaceticus and Alcaligenes odorans. J. Appl. Bacteriol., 81: 355-362.

Leahy JG, Colwell RR. 1990. Microbial degradation of hydrocarbons in the environment. Microbiol. Rev., 54: 305315.

Nwachukwu SCU, Ugoji EU. 1995. Impacts of crude petroleum spills on microbial communities of tropical soil. Int. J. Ecol. Environ. Sci., 21: 169-176.
Obbard JP, NG KL, Xu R. 2004. Biorremediation of petroleum contaminated beach sediments: use of crude palm oil and fatty acids to enhance indigenous biodegradation. Water Air Soil Pollut., 157: 149-161.

Odiete WO. 1999. Hydrocarbons pollution. In Environmental Physiology of Animals and Pollution (vol 1). Diversified Resources Ltd.: Lagos, Nigeria; 180-192.

Okpokwasili GC, James WA. 1995. Microbial contamination of kerosene, gasoline, and crude oil and their spoilage potentials. Material u Organismen, 29: 147-156.

Röling WFM, Milner MG, Jones DM, Lee K, Daniel F, Swannell RJP, Head IM. 2002. Robust hydrocarbon degradation and dynamics of bacterial communities during nutrient-enhanced oil spill bioremediation. Appl. Env. Microbiol., 68: 5537-5548.

Smith G. 1969. Classification and identification of fungi. In Introduction to Industrial Mycology (vol 1, $6^{\text {th }}$ edn). Edward Arnold: London; 56-144.

Widdel F, Rabus R. 2001. Anaerobic biodegradation of saturated and aromatic hydrocarbons. Curr. Opin. Biotechnol., 12: 259-276. 